\title{
Prognostic factors for chronic arthritis in children with acute joint swelling
}

\author{
Skirmante Rusoniene", Violeta Panaviene, Audrone Eidukaite, Marija Jakutovic \\ From 21st European Pediatric Rheumatology (PReS) Congress \\ Belgrade, Serbia. 17-21 September 2014
}

\section{Introduction}

Acute inflammatory arthritis is frequent clinical sign in children with variable outcomes. Often post infectious or viral arthritis progress to chronic joint disease

\section{Objectives}

Our aim is to determine prognostic factors that predict the course of chronic arthritis in children.

\section{Methods}

116 consecutive children with acute arthritis with symptoms duration $<6$ weeks included in prospective study. A standardize rheumatologic evaluation was performed on newly referred patients. Possible diagnostic variables collected at the first visit: active joints count, symptoms duration, time of morning stiffness, erythrocyte sedimentation rate (ESR), $C$ reactive protein (SRP), antinuclear antibodies (ANA), HLA B27, myeloid-related protein 8/14 (MRP8/14) and IL-6. Arthritis outcome was defined at 1 and 2 years follow-up. We considered the clinical outcomes - chronic arthritis and inactive disease. Multiple linear regression with forward stepwise was used to determine the prognostic variables.

\section{Results}

109/116 patients completed follow -up period. Of all patients $36,7 \%$ had clinically active (or chronic) arthritis after 1 year, and $30 \%$ - after 2 year follow-up periods, and had been treated with appropriate therapy after establishing initial diagnose (JIA, arthritis related to infections and self-limited undifferentiated arthritis). The mean serum level of MRP8/14 at baseline measured in patients with arthritis related to infection was $11233,74 \mathrm{ng} / \mathrm{ml}$, and $7836,05 \mathrm{ng} / \mathrm{ml}$ in JIA patients, compared with self-limiting arthritis $-4832,19 \mathrm{ng} / \mathrm{ml}(\mathrm{p}<0,001)$. Predominantly very

Children Hospital, Affiliate of Vilnius University Hospital Santariskiu Klinikos, Vilnius, Lithuania high MRP8/14 concentrations were measured in patients who developed chronic disease.

Logistic regression analysis showed that significant predictors of chronic disease were presence of morning stiffness (OR 8,7 [2,15-35,04]), arthritis in $\geq 5$ joints(OR $6,3[2-19,9])$ and MRP8/14 concentration $>5785 \mathrm{ng} / \mathrm{ml}$ (OR 4,4 [1,59-12,01]) at baseline.

\section{Conclusion}

The early presence of morning stiffness, polyarthritic joint involvement and high MRP8/14 concentration in a child with acute arthritis indicates the likelihood of chronic disease after 1 and 2 years follow-up.

\section{Disclosure of interest}

None declared.

Published: 17 September 2014

doi:10.1186/1546-0096-12-S1-P51

Cite this article as: Rusoniene et al:: Prognostic factors for chronic arthritis in children with acute joint swelling. Pediatric Rheumatology 2014 12(Suppl 1):P51.

Submit your next manuscript to BioMed Central and take full advantage of:

- Convenient online submission

- Thorough peer review

- No space constraints or color figure charges

- Immediate publication on acceptance

- Inclusion in PubMed, CAS, Scopus and Google Scholar

- Research which is freely available for redistribution 